\title{
A propriedade como fundamento ético-jurídico e econômico-político em Locke
}

\author{
The property as ethical and legal basis \\ and economic and political in Locke
}

Luiz Carlos Mariano da Rosa

\section{Resumo}

Se a lei natural autoriza o exercício da propriedade através do trabalho, a acumulação de riquezas, baseada na invenção do dinheiro, converge para transformar as diferenças físicas, intelectuais e morais em desigualdade de direito na instituição do Estado jurídico. Atribuindo a condição de propriedade ao trabalho a teoria de Locke dissimula a desigualdade através da "igualdade de relaçōes" de indivíduos abstratos em um sistema jurídico-político que encerra uma liberdade proporcional ao status dos indivíduos como agentes econômicos. Ora, se cabe à sociedade política a delimitação das obrigaçōes da lei natural, o que se impōe ao direito de propriedade individual é a restrição do seu exercício à necessidade, tendo em vista as múltiplas formas que pode assumir como mercadoria nas relaçōes de troca, que implicam a força de trabalho como objeto de troca e consumo em uma formação econômico-social que torna o homem uma simples mercadoria.

Palavras-chave: Locke; Direito Natural; Trabalho; Propriedade; Desigualdade.

\begin{abstract}
If natural law authorizes the exercise of property through work, the accumulation of wealth, based on the invention of money, converges to transform the physical, intellectual and moral differences in inequality of law in the institution of legal State. Assigning the property status to work Locke's theory conceals inequality by "equal relations" abstract individuals in a legal and political system that closes a freedom commensurate with the status of individuals as economic agents. But if it is for the political society the definition of the obligations of the natural law, which applies to individual property rights is the restriction of its use to the need, given the many forms it can take commodity terms of trade, which involve the workforce as an object of exchange and consumption in a social-economic formation that makes man a mere commodity.
\end{abstract}

Keywords: Locke; Natural Law; Job; Property; Inequality. 


\section{Aspectos Introdutórios}

À condição imperfeita que caracteriza a existência humana no estado de natureza, o que se impõe é a necessidade da instituição de um direito que, baseado no direito natural, seja assegurado pela coercibilidade que a instauração da sociedade política viabiliza, o que pressupōe que a caução social não guarda suficiência neste sentido que implica uma relação de dependência dos homens, no processo interindividual, no que concerne à razão e à consciência e antes à atividade que a encerra como tal nas fronteiras da sensação, a saber, a reflexão, convergindo o sistema filosófico-político de Locke para um racionalismo moral ${ }^{1}$, tendo em vista a concepção de que "ser-nos-á apropriado, como criaturas racionais, empregar as faculdades que temos a respeito das coisas que são mais adaptadas, e seguir a orientação da natureza, onde parece nos indicar o caminho" (LOCKE, 1999, IV, XII, 11, p. 282).

Nesta perspectiva, que encerra uma lei natural ou lei divina caracterizando a ordem natural das coisas, o direito à vida, o direito à felicidade e o direito à liberdade não guardam o mesmo sentido entre os indivíduos que através do consentimento instituem a sociedade política, divergindo em função da condição de desigualdade que os caracteriza no âmbito da organização político-social que, segundo a concepção de Locke, traz como fundamento ético-jurídico e econômico-político a propriedade, convergindo para uma determinada formação econômico-social e para um específico arcabouço de relaçōes produtivas.

Estabelecendo o direito de propriedade através de um conceito que, além da terra, envolve a vida, a liberdade, o corpo, o trabalho, Locke institui uma sociedade política que, tendo como fundamento tal direito, coloca em jogo tudo o que não seria passível de troca e que, dessa forma, é relegado às fronteiras do regime de relaçōes econômico-sociais ora instauradas, o que implica em um direito paradoxal, que reúne noçōes contraditórias, antagônicas, autoexcludentes, cujo conteúdo corresponde ao status dos indivíduos como agentes econômicos em um sistema jurídico-político que tende a distinguir "proprietários" e "trabalhadores", detentores dos meios de produção e titulares da força de trabalho.

Convergindo para uma espécie de "seleção" que tende à hierarquização da totalidade político-social, o que se impōe, nesta perspectiva, é a determinação a priori da estrutura jurídico-política do Estado (liberal) e do modus operandi da sua formação econômico-social, tendo em vista o direito de propriedade que, guardando anterioridade em relação à instituição do poder político, emerge, no tocante aos bens (fortunas), como resultado do trabalho e do investimento do agente ao qual cabe, em sua realização, corresponder às leis naturais que regem a existência humana, submetendo-se aos princípios do direito natural.

Se a existência humana no estado de natureza se mantém sob a égide do poder moral que, em função do direito natural, se lhe é imposto, o caráter condicional que carrega demanda a instauração da sociedade política e de um poder institucional individualizado (estatal) que atenda à necessidade de garantia jurídica específica, encarnando a coercibilidade através de um exercício delimitado pela condição de liberdade dos indivíduos como membros do Estado cujo governo, circunscrito objetivamente ao bem público, não tem autorização de gerir, reger, dirigir o âmbito que encerra o que se lhes é próprio, a saber, a sua particularidade em si, a sua singularidade como tal.

A instauração da sociedade política atende à necessidade que envolve a instituição da coer-

\footnotetext{
${ }^{1}$ Nesta perspectiva, convém ressaltar a tensāo que se impōe à teoria moral de Locke, cujo conteúdo traz como fundamento tanto o racionalismo como o hedonismo, à medida que se atribui à razão a capacidade de determinar aquilo que se caracteriza como verdadeiramente bom, este guarda a condição que implica a produçāo de prazer: "A ética de Locke é de caráter hedonista na medida em que atribui considerável importância às causas do prazer e da dor como 'bens' e 'males', respectivamente. No entanto, esse 'prazer' e essa 'dor' (ou suas causas) não devem ser entendidos apenas no sentido 'físico' ou apenas no sentido 'subjetivo'. Segundo Locke, há leis morais cuja obediência produz o bem e cuja desobediência produz o mal. Essas leis, embora procedam de Deus, sāo racionais e coincidem com 'as leis naturais'." (MORA, 2004, p. 1769)
} 
cibilidade concernente às leis naturais através do estabelecimento de um poder institucional individualizado que guarde capacidade de se impor aos indivíduos pelo exercício do constrangimento, cuja força emerge da autorização contratual e traz o consentimento da maioria como fundamento da sua atualização².

Nessa perspectiva, o Direito válido igualmente para todos não se impõe senão às prerrogativas dos homens como proprietários de bens (fortunas), cuja condição possibilita a construção de individualidades que juridicamente alcançam primazia em detrimento dos demais membros da sociedade que em face da privação do referido patrimônio permanecem relegados à inferioridade em um sistema filosófico-político que tende a justificar tal desigualdade em função das diferenças físicas, intelectuais e morais dos indivíduos e em virtude da sua conduta em relação ao fundamento ético-jurídico e econômico-político estabelecido ${ }^{3}$.

Se o trabalho implica um processo que encerra a transformação da posse em propriedade ${ }^{4}$, o resultado para o qual converge tal investimento, longe de se restringir à satisfação de seus carecimentos, tende a multiplicá-los incessantemente em uma reação em cadeia que demanda a ampliação das forças de produção que, trazendo o material humano como fator indispensável, atribui aos indivíduos uma condição de antagonismo irremediável, implicando uma oposição que guarda complementariedade em um movimento que culmina na subjugação dos trabalhadores que, em face da necessidade de autoconservação, são induzidos pela lógica da organização econômico-social à alienação da sua capacidade de produção, perfazendo um contexto que os relega à margem do sistema político, se lhes negando cidadania e antes racionalidade ${ }^{5}$.

Um dos pressupostos do trabalho assalariado e uma das condições históricas do capital é o trabalho livre e a troca de trabalho livre por dinheiro, com o objetivo de reproduzir o dinheiro e valorizá-lo; de o trabalho ser consumido pelo dinheiro - não como valor de uso para o desfrute, mas como valor de uso para o dinheiro. Outro pressuposto é a separação do trabalho livre das condições objetivas de sua efetivação - dos meios e do material do trabalho. (MARX, 1985, p. 65)

Nesta perspectiva, a invenção do dinheiro emerge como produto do consentimento tácito dos indivíduos no estágio pré-cívico, convergindo para possibilitar a ilimitada acumulação de propriedades (terras) que, engendrando o trabalho assalariado ${ }^{6}$ e a divisão de classes, contribui para converter

\footnotetext{
${ }^{2}$ Tendo em vista que "os homens são pouco inclinados para a razāo e contornam a obrigação da lei natural, quando não a ignoram pura e simplesmente." (MICHAUD, 1991, p. 26)

${ }^{3}$ Eis o argumento de Locke acerca da atribuição de primazia de alguns indivíduos em detrimento de outros em sua teoria: “Embora eu tenha dito anteriormente que, por natureza, todos os homens são iguais, não se pode supor que eu me referisse a todos os tipos de igualdade. A idade ou a virtude podem dar aos homens uma precedência justa. A excelência dos talentos e dos méritos pode colocar alguns acima do nível comum. 0 nascimento pode sujeitar alguns, e a aliança ou os beneficios podem sujeitar outros, reconhecendo-se aqueles a quem a natureza, a gratidāo ou outros aspectos possam obrigar." (LOCKE, 2001, VI, § 54, p. 114)

4 "Ainda que a terra e todas as criaturas inferiores pertençam em comum a todos os homens, cada um guarda a propriedade de sua própria pessoa; sobre esta ninguém tem qualquer direito, exceto ela. Podemos dizer que o trabalho de seu corpo e a obra produzida por suas māos sāo propriedade sua. Sempre que ele tira um objeto do estado em que a natureza o colocou e deixou, mistura nisso o seu trabalho e a isso acrescenta algo que lhe pertence, por isso o tornando sua propriedade" (LOCKE, 2001, V, § 27, p. 98). Eis o argumento de Locke que, atribuindo ao trabalho a capacidade de realizar a transposiçāo da posse comum da terra para a propriedade privada, torna dispensável o consentimento de todos os demais indivíduos, contrapondo-se à perspectiva de Filmer, que caracteriza como inviável tal operação: "Certamente seria uma rara felicidade que, em um instante do tempo, todos os homens no mundo concordassem juntos em uma ideia de mudar a comunidade natural de todas as coisas em domínio privado. Pois sem tal consentimento unânime não seria possível alterar a comunidade. Basta que um homem no mundo dissentisse para que a alteraçāo tivesse sido injusta, porque este homem tinha 0 direito ao uso comum de todas as coisas no mundo pela lei da natureza, de modo que dar a propriedade de algo a alguém teria sido roubá-lo de seu direito ao uso comum de todas as coisas." (FILMER, 1991, p. 234)

${ }^{5}$ Tendo em vista a perspectiva que assinala que somente os proprietários de bens ou fortunas "têm pleno interesse na preservação da propriedade, e apenas esses são integralmente capazes de vida racional - aquele compromisso voluntário para com a lei da razão - que é a base necessária para a plena participação na sociedade civil." (MACPHERSON, 1979, p. 260)

${ }^{6}$ Conforme esclarece Macpherson, a invenção do dinheiro possibilita a aquisiçāo de propriedades e o seu acúmulo pelos indivíduos, acarretando um desequilíbrio econômico-social, à medida que institucionaliza o "trabalho assalariado", pois "numa economia comercial em que toda a terra está apropriada,
} implicava na existência de trabalho assalariado." (MACPHERSON, 1979, p. 229) 
as diferenças físicas, intelectuais e morais em desigualdades que o contrato de Locke tende a legitimar, à medida que institui o Estado jurídico, que assegura o exercício dos direitos naturais aos seus membros desde que os tais sejam também cidadãos cuja condição, no sistema filosófico-político em questão, demanda não somente a titularidade do corpo, da vida, da liberdade, senão inclusive - e principalmente - de bens (fortunas), sem os quais não podem eleger os representantes e magistrados que hão de compor o governo.

As condiçōes jurídicas da sociedade civil - enquanto constituída por membros dentre os quais aos cidadãos cabem a eleição dos que hão de elaborar em seu nome a legislação -, não consistem senão no fundamento da sujeição do poder ao direito, convergindo para uma relação envolvendo o povo e o Estado, a sociedade civil e o governo civil, que implica a subordinação deste último à lei que representa para o primeiro a própria condição de existência.

\section{A propriedade como base das relações interindividuais: 0 fundamento ético- lógico da transição do estado de natureza para o estado cívico}

Ao direito natural, no âmbito do estado de natureza, a despeito da sua validade por si, o que cabe é uma experiência que escapa à coercibilidade do poder institucional individualizado e à objetividade conferida pela positividade jurídica, à medida que permanece sob a égide pré-categorial, o que implica a necessidade da sua corporificação em juízos normativos, cuja sistematização encerra um conteúdo originário que se impōe às relaçōes interindividuais e torna-se passível de promulgação pelo legislativo no processo de transição para o estado cívico, convergindo para a formalização de valoraçōes jurídicas.

As obrigaçōes da lei da natureza não se extinguem na sociedade, mas em muitos casos elas são delimitadas mais estritamente e devem ser sancionadas por leis humanas que lhes anexam penalidades para garantir seu cumprimento. Assim, a lei da natureza impōe-se como uma lei eterna a todos os homens, aos legisladores como a todos os outros. (LOCKE, 2001, XI, § 135, p. 164)

Oriunda de Deus, à lei natural7, segundo a teoria de Locke, o que se impōe, caracterizando-a como tal, é o poder de execução que, no estado de natureza, cabe ao indivíduo levar a efeito diante da ruptura da sua condição de paz em face da possibilidade de risco envolvendo a preservação tanto de si mesmo como dos outros. Se a lei natural ${ }^{8}$ implica o dever envolvendo a preservação tanto de si próprio como dos outros, à medida que não encerra senão a necessidade de manutenção da paz e de conservação do gênero humano, ao estado de natureza a teoria de Locke atribui um caráter social, tendo em vista a incompatibilidade entre as regras morais da lei natural e um hipotético estado de confronto ininterrupto entre os homens.

Se à razão humana o que se impõe é a capacidade de orientação que implica a correlação envolvendo necessidade e utilidade no que concerne ao seu ser, constituindo-se a sua aplicação a lei natural propriamente, guardando anterioridade em relação a todos os deveres, o desejo e a busca da felicidade consistem em um direito absoluto, um direito natural que, segundo a teoria de Locke, emerge como universalmente efetivo, constituin-

\footnotetext{
${ }^{7}$ Nesta perspectiva, alcança relevância a observação de Strauss: "A condição em que o homem vive no estado de natureza - os 'perigos contínuos' e a 'penúria' - impossibilita o conhecimento da lei natural: no estado de natureza a lei natural não é promulgada. Como a lei natural, para ser uma lei no sentido próprio do termo, tem de ser promulgada no estado de natureza, somos uma vez mais forçados a concluir que a lei natural não é uma lei no sentido próprio do termo." (STRAUSS, 2009, p. 194)

${ }^{8}$ Convém assinalar a indefiniçāo de Locke no sentido de estabelecer o fundamento da "força da obrigaçāo" da lei natural, tendo em vista que "permanece dividido entre uma concepção voluntarista nominalista da lei natural e uma posição ontológica intelectualista", à medida que se a primeira consiste em "uma submissão à vontade superior detentora das sançōes do além", a segunda implica o "reconhecimento intelectual da ordem das coisas", convergindo para a conclusāo de que se àquela "ameaça abalar o aspecto natural e racional da lei 'natural", esta última "enfraquece a pressão da lei, ao mesmo tempo em que a torna mais 'natural'." (MICHAUD, 1991, p. 25)
} 
do-se o fundamento da lei natural, visto que se esta última não se caracteriza como inata, o referido direito é inerente ${ }^{9}$. Se a realização da felicidade depende da vida, pressupondo-a, a possibilidade de uma oposição entre a busca da felicidade e o desejo de vida atribui a este último preeminência, convergindo a autopreservação para as fronteiras que encerram uma necessidade natural, que se Ihe implica a condição de um direito fundamental, que se sobrepõe a todos os outros.

Nessa perspectiva, se o direito natural pressupōe equilíbrio nas relações econômico-sociais, no intercâmbio de bens ou propriedades (no caso em que há um comércio que envolva o trabalho) entre dois ou mais membros da sociedade, a injustiça demanda uma compensação proporcional ao prejuízo, correspondente ao dano, tendo em vista a necessidade de "reparação" de uma ação que, contrariando as leis naturais, nega o princípio de igualdade moral e acarreta uma dívida, outorgando à vítima ou aos demais homens direta ou indiretamente envolvidos na situação o poder de corrigir o erro, penalizando o infrator, o que implica um consentimento implícito ou explícito e uma convenção neste sentido.

Se a justiça, nessa perspectiva, baseada no direito natural, guarda raízes nas fronteiras que encerram a noção de ordem ou medida, correspondendo à condição originária do homem, a injustiça emerge como um desequilíbrio instaurado no comércio envolvendo bens ou propriedades que pressuponha uma alteração incompatível com o princípio da igualdade moral que resulte em um excesso para uma das partes em detrimento da outra.

Sobrepondo-se ao Estado enquanto forma institucional que advém através do contrato que instaura a sociedade civil e o governo civil, o indivíduo singular tem valor em si mesmo, o que implica a primazia dos direitos em relação aos deveres em um sistema filosófico-político que encerra como fim da ordem político-social a criação de condiçōes que possibilitem o desenvolvimento máximo da individualidade, convergindo a satisfação das suas necessidades e a conquista da felicidade para as fronteiras que perfazem o fundamento da noção de justiça.

Se a lei natural (original) autoriza a apropriação de terras, ouro e prata, entre outras coisas, segundo a sua capacidade de trabalho e de acordo com os meios e recursos de utilização que dispõe o indivíduo, e se a invenção do dinheiro contribui para tornar ilimitado tal processo, resultando na acumulação de riquezas em detrimento dos demais $^{10}$, a instituição da sociedade política converge para a delimitação das obrigaçōes da lei natural, o que implica que, em função da equidade, o direito de propriedade individual esteja atrelado à necessidade e não à possibilidade de uso, tendo em vista as múltiplas formas que pode assumir como objeto (mercadoria) nas relaçōes de troca, acarretando efeitos econômico-sociais incontroláveis e incontornáveis ${ }^{11}$.

Guardando correspondência com a igualdade, que longe de consistir naquilo que exclui as dife-

\footnotetext{
9 “O desejo de felicidade e a prossecução da felicidade têm o carácter de um direito absoluto, de um direito natural. Há, então, um direito natural inato, ao passo que não há qualquer dever natural inato. Para compreender como isso é possível, basta reformular a nossa última citação: a prossecução da felicidade é um direito, 'tem de ser permitido', porque 'não pode ser impedido'. Trata-se de um direito que precede os deveres pela mesma razāo que, segundo Hobbes, estabelece o direito de preservação de si mesmo como o facto moral fundamental: tem de se permitir que o homem defenda a sua vida contra a morte violenta porque é levado a fazê-lo por uma certa necessidade natural semelhante à que arrasta uma pedra que cai." (STRAUSS, 2009, p. 194)

${ }^{10}$ Sobrepondo-se à possibilidade de uma discordância em relação à instituição do dinheiro e à medida de valor estabelecida através do consentimento, Locke justifica a "posse desproporcional e desigual da terra", afirmando que "através de um consentimento tácito e voluntário, eles descobriram e concordaram em uma maneira pela qual um homem pode honestamente possuir mais terra do que ele próprio pode utilizar seu produto, recebendo ouro e prata em troca do excesso, que podem ser guardados sem causar dano a ninguém; estes metais não se deterioram nem perecem nas mãos de seu proprietário. Esta divisão das coisas em uma igualdade de posses particulares, os homens tornaram praticável fora dos limites da sociedade e sem acordo, apenas atribuindo um valor ao ouro e à prata, e tacitamente concordando com o uso do dinheiro." (LOCKE, 2001, V, § 50, p. 111)

${ }^{11}$ Se a lei natural autoriza a apropriaçāo de terras, ouro e prata correspondente à possibilidade de uso, tendo em vista a ilimitada prodigalidade da natureza e a necessidade que envolve a sua conservação, além do fato de que o ouro e a prata não possuíam valor em si, em face da escassez dos referidos bens que caracteriza a transição do estado de natureza para o estado cívico, convém destacar que "seria, portanto, de esperar que a lei natural original tivesse sido substituída por regras que impusessem restriçōes muito mais apertadas à apropriaçāo do que as que existiam no estado de natureza." (STRAUSS, 2009, p. 205)
} 
renças físicas, intelectuais e morais, a saber, uma identidade, emerge como um valor moral, a liberdade, segundo a teoria de Locke, sobrepondo-se à limitação imposta pelos direitos dos outros indivíduos, pressupõe uma relação de dependência recíproca e responsabilidade mútua que a necessidade do exercício do direito de propriedade não pode contradizer sob pena de tornar paradoxal a autodeterminação da subjetividade e a auto-obrigação da objetividade, tendo em vista a ilimitada apropriação de terras que implica a capacidade de usar meios e recursos no sentido de se lhe conferir um status produtivo que demanda, consequentemente, a admissão do trabalho assalariado ou antes a possibilidade que envolve a alienação daquilo que é próprio ao homem em função da sua autoconservação (a saber, o corpo, a vida, o trabalho, a liberdade), convergindo para a divisão social do trabalho, o trabalho assalariado e a divisão de classes em um processo de hierarquização que tende a negar as premissas que fundamentam a referida concepção ${ }^{12}$.

\section{A propriedade como base do sistema jurídico-político: do Direito Natural ao Direito Positivo e a capacidade de autodeterminação e de auto-obrigação do indivíduo}

Assim, a liberdade de um homem e sua faculdade de agir segundo sua própria vontade estão fundamentadas no fato dele possuir uma razão, capaz de instruí-lo naquela lei pela qual ele vai ser regido, e fazer com que saiba a que distância ele está da liberdade de sua própria vontade. (LOCKE, 2001, $\mathrm{VI}, \S 63$, p. 119)
Se o direito natural caracteriza-se como racional, consistindo a possibilidade envolvendo o seu conhecimento no resultado de um processo que demanda o exercício da reflexão, o que se impōe às leis naturais é uma experiência que converge para as fronteiras que encerram um viés "histórico", à medida que a sua objetividade ética escapa à relação imediata entre os homens e o mundo pressuposta na condição de existência do estado de natureza, a despeito da imanência que carrega, tendo em vista que a correspondência em questão atrela determinação e consciência, perfazendo uma auto-obrigação que em face da "positividade" da particularidade tende a anular os efeitos da negatividade na elaboração da forma necessária que cabe à vontade moral em seu movimento de exteriorização.

Nesta perspectiva, o que se impōe é a primazia da natureza em relação ao artifício representado pela sociedade política que, tendo como fundamento uma convenção, não guarda capacidade de atender às necessidades humanas senão correspondendo aos princípios, valores e fins que se Ihe mantém anterioridade, a saber, aqueles que constituem as leis naturais e que sob a condição de imanência demandam a atividade reflexiva para o seu conhecimento como tais, a consciência, a vontade moral.

Subtrair o direito natural da condição de fundamento da legislação positiva e antes da vontade moral converge para as fronteiras que implicam a institucionalização de noçōes múltiplas e contraditórias envolvendo o bem e o mal, o justo e o injusto, seja no âmbito das relaçōes intercomunitárias, intergrupais, seja na esfera das relaçōes interindividuais, convergindo para a impossibilidade da sociabilidade senão sob a égide de um poder institucional

\footnotetext{
${ }^{12}$ Conforme exemplifica a exposição que Locke desenvolve acerca da condição de servidão atribuída tanto ao trabalhador assalariado como ao escravo, entre os quais institui uma relaçāo de identidade, distinguindo-os daquele que se thes guarda preeminência, a saber, o senhor: "Senhor e servo sāo nomes tão antigos quanto a história, mas dados a indivíduos de condiçōes bem diferentes; um homem livre torna-se servidor de outro quando lhe vende um certo tempo de serviço que realiza em troca de um salário que deve receber; e embora isso em geral o coloque dentro da família de seu senhor e recaia sob o jugo da disciplina geral que a comanda, isso proporciona ao senhor um poder temporário sobre ele, mas não maior que aquele contido no contrato entre eles. Mas há uma outra categoria de servidores, a que damos o nome particular de escravos, que, sendo cativos aprisionados em uma guerra justa, estāo pelo direito de natureza sujeitos à dominação absoluta e ao poder absoluto de seus senhores. Como eu disse, estes homens tiveram suas vidas capturadas, e com elas suas liberdades, perderam seus bens - e estão, no estado de escravidão, privados de qualquer propriedade - e não podem nesse estado não poder ser considerados parte da sociedade civil, cujo principal fim é a preservaçāo da propriedade." (LOCKE, 2001, VII, § 85, pp. 131-132)
} 
absoluto à la Hobbes que através do monopólio da força e da coercibilidade guarde capacidade de instaurar o Direito objetivamente válido.

A necessidade da existência de um conceito do jurídico que possibilite a distinção e o conhecimento do fato jurídico - eis o que se impōe à concepção que atribui aos valores a condição de um produto da civilização, tendo em vista que, a despeito daqueles que guardam correspondência com a experiência histórica, torna-se relevante o valor da pessoa humana que, emergindo como princípio da ideia do justo (valor-fonte), consiste em um pressuposto dos ordenamentos jurídicos, fundamentando o processo da ordem jurídica positiva, à medida que a condição da própria experiência jurídica se lhe está imbricada.

Se a adesão ao direito natural e às suas leis não se caracteriza senão como convencional no estado de natureza, a instituição da sociedade civil e do poder político converge para assegurar, mediante a concepção hobbesiana da soberania estatal, a possibilidade de obediência dos indivíduos que através do contrato se tornaram seus membros, perfazendo o sistema filosófico-político de Locke uma construção que dissimula a arbitrariedade, à medida que confere supremacia a um poder (legislativo ${ }^{13}$ ) que, representando a sociedade, é constituído por indivíduos eleitos pelos cidadãos ${ }^{14}$, a saber, aqueles que são proprietários, na acepção da palavra, proprietários, não no sentido da titularidade de um patrimônio que jamais estará em questão (corpo, vida, trabalho) senão segundo a noção do bem concreto passível de disputa e cuja posse define e fundamenta a formação econômico-social e jurídico-política: a terra como meio de produção.
Prescindindo de garantia jurídica específica, o que se impõe ao direito natural é uma condição que se circunscreve às fronteiras que implicam a segurança, a responsabilidade, a caução social, cuja coercibilidade não transpõe o caráter relativo, tornando condicional a sua obrigação, demandando a instituição de um poder ${ }^{15}$ que, instaurando o Direito Positivo, seja capaz de exercer a coação jurídica destinada à realizá-lo através de um processo que não comprometa a liberdade e a igualdade dos indivíduos, tendo-os como a sua origem e fim.

A capacidade de autodeterminação e de auto-obrigação do indivíduo demanda que no processo de transição do estado natural para o estado cívico a instituição da sociedade política e do poder de legislar, tendo como fundamento o direito natural, guarde a pressuposição de uma concessão ou reconhecimento de uma autonomia relativa cujo objetivo não envolve senão a definição de uma garantia jurídica em face de um conteúdo pré-existente que consiste na matéria-prima do Direito Positivo, conferindo validade às leis positivas ou civis ora promulgadas, à medida que as condiciona e delimita.

\section{A propriedade como base da existência histórico-cultural: da "utilidade" no princípio de apropriação à maximização da "utilidade" na acumulação ilimitada}

"Tudo o que um homem pode utilizar de maneira a retirar uma vantagem qualquer para sua existência sem desperdício, eis o que seu traba-

\footnotetext{
${ }^{13}$ Nesta perspectiva, alcança relevância a interpretação de Pierre Manent que, atribuindo ao poder legislativo a condição de "prolongamento do desejo individual de preservaçāo", supōe que "é por exprimir diretamente o desejo de conservação da propriedade, razão de ser da instituição política, que ele é soberano ou 'supremo'." (MANENT, 1990, p. 79, grifo meu)

${ }^{14}$ Conforme esclarece Macpherson, que afirma que "o direito a uma voz nas eleiçōes não era inerente a todos, porque nem todos haviam preservado aquela parte da sua liberdade humana que consistia na propriedade do próprio trabalho. O sufrágio era necessário e podia ser reivindicado somente pelos que haviam preservado essa propriedade, e cuja vida econômica por conseguinte era de empreendimentos vivos. (...) Os assalariados e os mendigos, tendo perdido a propriedade do seu próprio trabalho - poderíamos supor - não tinham propriedades. Portanto, não tinham interesse, em nenhuma das funçōes do governo: nem na primordial, nem na secundária, igualmente necessária." (MACPHERSON, 1979, p. 156)

15 "Os direitos naturais não têm força: é indispensável constituir um poder que os enuncie e formalize - que lhes dê força de lei - e que imponha sua efetividade (mediante a coerção)." (CHÂTELET; DUHAMEL; PISIER-KOUCHNER, 1990, p. 59, grifos do autor)
} 
Iho pode fixar como sua propriedade" (LOCKE, 2001, V, § 31, p. 100) ${ }^{16}$. O trabalho que instaura o processo que transforma a posse em propriedade não consiste senão no momento da igualdade moral dos homens em sua condição originária no estado de natureza, perfazendo tal investimento na aplicação dos atributos e recursos pessoais em função do referido objetivo, o que implica um movimento que pressupōe uma liberdade condicionada pelo exercício da capacidade de correlacionar meios e fins através de esquemas que divergem entre os indivíduos em virtude das diferenças físicas, intelectuais e morais que se lhes distinguem e tendem a se lhes guardar possibilidade de proporcionar diversos resultados, haja vista que

embora as coisas da natureza sejam dadas em comum, o homem, sendo senhor de si mesmo e proprietário de sua própria pessoa e das açōes de seu trabalho, tem ainda em si a justificação principal da propriedade; e aquilo que compôs a maior parte do que ele aplicou para o sustento ou o conforto de sua existência, à medida que as invençōes e as artes aperfeiçoaram as condições de vida, era absolutamente sua propriedade, não pertencendo em comum aos outros. (LOCKE, 2001, V, § 44, p. 108)

Pré-existente ao estado civil, ao direito de propriedade cabe o equilíbrio entre liberdade $e$ igualdade em uma relação que, implicando não somente a terra mas a vida, o corpo, o trabaIho, não converge senão para um resultado que permanece supostamente sob a égide de um sistema ético-lógico que guarda caráter de imanência no que concerne à existência humana e se lhe determina o destino histórico-cultural, sobrepondo-se às condições objetivas da vida econômico-social, que corresponde a uma rea- lidade que traz subjacente um processo no âmbito do qual a produção humana carrega a imbricação que envolve uma inter-relação de fatores que escapam à regularidade de um conjunto de causas e efeitos cujos princípios, inexoráveis, segundo a teoria de Locke, são capazes de condicionar a interação que abrange homem-natureza.

“Na origem da propriedade está, não a sociedade, mas o indivíduo - o indivíduo incentivado apenas pelo seu interesse próprio" (STRAUSS, 2009, p. 202). Consistindo em um direito que atribui aos indivíduos uma condição que encerra segurança e estabilidade, a propriedade, segundo a teoria de Locke, caracterizando-se como passível de acumulação ${ }^{17}$, converge para as fronteiras que encerram a divisão do trabalho e a divisão de classes em um sistema filosófico-político que estabelece a hierarquização dos homens que, classificados em virtude do suposto resultado obtido através do uso das suas capacidades e recursos físicos, intelectuais e morais, tornam-se opositores, à medida que nas relaçōes produtivas, cada qual, proprietários e não proprietários, precisa atender interesses contraditórios em um antagonismo que sobrepõe, ético-juridicamente e político-economicamente, os primeiros aos últimos, engendrando uma desigualdade incompatível com o princípio da perspectiva empregada, tendo em vista que, além de expor o tipo de racionalidade envolvida (a saber, instrumental), assinala a insegurança e a instabilidade que afetam ambas as partes, ao contrário do preconizado no início.

Se em um momento a produção se circunscreve ao consumo pessoal, a acumulação de terras demanda a divisão do trabalho, convergindo a

\footnotetext{
${ }^{16}$ Detendo-se no argumento do desperdício, eis a crítica de Strauss: "A lei natural em matéria de propriedade atenta na prevençāo do desperdício; ao apropriar-se de coisas através do seu trabalho, o homem tem de pensar exclusivamente na prevenção do desperdício; nāo tem de pensar nos outros seres humanos. Chacun pour soi; Dieu pour nous tous." (STRAUSS, 2009, p. 203)

${ }^{17}$ Tendo em vista o argumento que defende que sendo "possível trocar qualquer quantidade de produto por capital ativo, que nunca deteriora, nāo é injusto nem insensato acumular qualquer quantidade de terra, de modo a fazê-la produzir um excedente que possa ser convertido em dinheiro e usado como capital. A limitação do desperdício imposta pela lei natural foi tornada sem efeito respectivamente à acumulação de terras e de capital (...)." (MACPHERSON, 1979, p. 220)
} 
troca entre indivíduos para a organização de um sistema econômico-social que, trazendo a emergência do dinheiro e do comerciante, tende a instaurar relaçōes segundo a necessidade imanente e as leis internas que o perfazem como tal e cuja regulação guarda correspondência com o estágio de desenvolvimento de uma determinada forma de produção em um processo que encerra a força de trabalho como objeto de troca e consumo, atribuindo ao homem a condição de simples mercadoria ${ }^{18}$.

Atribuindo a condição de propriedade não apenas às posses de terras mas também ao trabaIho em si, além do corpo e da vida, o sistema filosófico-político de Locke dissimula a desigualdade através da "igualdade de relaçōes" de indivíduos abstratos em um sistema jurídico-político que encerra uma liberdade que guarda proporcionalidade, contudo, à posição ocupada e à função cumprida na hierarquia da organização econômico-social, que por sua vez traz como determinação a riqueza material cuja base não se caracteriza senão pelo monopólio dos meios de produção e pela capacidade empregada na sua utilização no sentido de multiplicar o patrimônio financeiro, aumentando-o progressivamente para o bem-estar geral19.

Guardando possibilidade de resultar em um desequilíbrio econômico-social, a ilimitada apropriação de terras provoca um desajuste que tende ao agravamento em função da invenção do dinheiro, à medida que converge para a instauração do monopólio das riquezas
- e se o consentimento viabiliza tal condição, legitimando a desigualdade, a sua negação poderia ter interrompido um processo que, embora logicamente contrário ao direito natural $^{20}$, adquire base jurídica através do contrato de Locke que, dessa forma, multiplica as desigualdades, tendo em vista a necessidade dos "despossuídos" de realizarem, em nome da sua autoconservação, a alienação de tudo aquilo que jamais deveria ter sido colocado em jogo, a saber, a vida, o corpo, o trabalho.

Se a cidadania e os direitos políticos que competem à sua condição permanecem sob o poder dos proprietários de bens e posses, que perfazem uma minoria em relação à sociedade civil e aos seus membros, é o sistema representativo que possibilita que os seus interesses obtenham o consentimento da maioria, tornando-se fundamento para a promulgação da legislação que, destinada à totalidade político-social, beneficia somente os "representados", os "eleitores", em detrimento dos demais que, constituindo a maioria, comporão o conjunto dos governados, tendo em vista que

a classe operária, não tendo fortunas, está submetida à sociedade civil, mas dela não faz parte. (...) A ambiguidade com relação a quem é membro da sociedade civil em virtude do suposto contrato original permite que Locke considere todos os homens como sendo membros, com a finalidade de serem governados, e apenas os homens de fortuna para a finalidade de governar. (MACPHERSON, 1979, p. 260)

\footnotetext{
${ }^{18}$ Consistindo, segundo Locke, na "propriedade da pessoa humana enquanto sujeito de direitos naturais ou inatos ou racionais puros, que antecedem à constituição (histórica) do homem em sociedade", o trabalho, esclarece Galvano Della Volpe, guardando a acepção de "propriedade-direito" da pessoa humana, fundamenta filosoficamente a "concepçāo econômica burguesa da força de trabalho como algo de privado, ocasiāo, portanto, de relaçōes de indivíduo a indivíduo, e numa palavra objeto de troca, mercadoria (e não apenas a base da propriedade privada da terra trabalhada, segundo Locke)." (DELLA VOLPE, s.d., pp. 31-32)

${ }^{19}$ Tendo em vista a perspectiva que assinala que "aquele que se apropria da terra por meio de seu trabalho nāo diminui, mas aumenta a reserva comum da humanidade. Pois as provisōes que servem para o sustento da vida humana, produzidas por um acre de terra cercado e cultivado, sāo dez vezes maiores que aquelas produzidas por um acre de terra de igual riqueza, mas inculta e comum. Por isso, pode-se dizer que aquele que cerca a terra e retira de dez acres uma abundância muito maior de produtos para o conforto de sua vida do que retiraria de cem acres incultos, dá na verdade noventa acres à humanidade" (LOCKE, 2001, V, § 37, p. 104). Eis o princípio que se impōe à noçāo de bem-estar geral, segundo a teoria de Locke que, estabelecendo uma relação envolvendo a primazia da terra cultivada diante da terra inculta, converge para a transposiçāo que implica a propriedade privada e a propriedade comum.

${ }^{20}$ Tendo em vista que no estado de natureza "a lei natural podia permanecer em silêncio quanto aos interesses e necessidades dos outros homens porque essas necessidades eram supridas pela 'nossa māe comum'; por mais que um homem com o seu trabalho apropriasse, havia o 'suficiente e igualmente bom em comum para os outros'." (STRAUSS, 2009, p. 203)
} 
Atribuindo a condição de cidadania aos proprietários de bens e posses, a teoria de Locke exclui os não proprietários de bens materiais do processo jurídico-político que determina o destino do Estado, relegando os tais às fronteiras da esfera econômico-social e à função produtiva em um sistema que, dessa forma, corresponde à hierarquia que encerra a distinção entre as individualidades, sobrepondo as individualidades dos proprietários às individualidades dos não proprietários, negando-as, convergindo para conferir ao "ter" preeminência em relação ao "ser" através de uma lógica que torna a racionalidade causa e efeito deste princípio de avaliação ${ }^{21}$.

Nessa perspectiva, à cidadania, segundo o sistema filosófico-político de Locke, o que se impōe é uma condição atribuída aos "proprietários" de bens ou fortunas, aos ricos, que se sobrepōem aos não proprietários (a saber, os trabalhadores), aos pobres, aos quais, relegados à margem do governo como tão somente membros da sociedade civil22, cabe cumprir o papel destinado à construção das riquezas em uma formação econômico-social que tende a tornar abstrata a igualdade, à medida que, não correspondendo à concreticidade histórico-cultural e econômico-social, converge para uma liberdade que não se the guarda senão proporcionalidade.

\section{A propriedade como base da formação econômico-social: a criação do dinheiro como mercadoria principal e a produção da riqueza monetária (capital)}

Método, racionalidade e objetividade - eis o que se impōe às relaçōes econômicas baseadas no regime de propriedade e que convergem, através da instauração do sistema monetário, para a produção de uma riqueza material que se sobrepōe ao patrimônio constituído por terras (ou rebanhos) e resulta no desenvolvimento de atividades comerciais abrangendo os produtos de consumo, perfazendo uma organização cuja complexidade é reduzida à relaçōes de mérito e à tendência que concebe o resultado como a exteriorização de princípios que guardam correspondência com a condição moral do indivíduo.

Os homens de perspectivas mais amplas são "os racionais", e que constituem uma minoria. Além disso, o verdadeiro trabalho pressupōe que o homem está disposto a, e é capaz de, se submeter ao fardo efectivo [sic] do trabalho em nome das conveniências futuras; e "os industriosos" constituem uma minoria. "Os preguiçosos e irreflectidos" [sic] constituem "de longe a maior parte do género humano". Por isso, a produção de riqueza exige que os industriosos e racionais tomem a dianteira e forcem os preguiçosos e irreflectidos [sic] a trabalhar contra a sua vontade para o seu próprio bem. (STRAUSS, 2009, p. 208)

Convergindo para uma racionalidade que, implicando um processo que tende à máxima abstração na elaboração de uma nova concepção do valor, traz como modus operandi um puro artifício humano, ao sistema monetário (ou à monetarização do sistema) impõe-se uma forma de relação de caráter positivo, que encerra uma experiência e uma prática que envolve uma noção quantitativa e econômica da coisa (objeto) como mercadoria em uma formação econômico-social que atribui ao crédito uma condição fundamental, à medida que, assumindo a titularidade das operaçōes mercantis, emerge simultaneamente como fundamento do poder da sociedade polí-

\footnotetext{
${ }^{21}$ Nesta perspectiva, convém recorrer a descrição de Locke da condição da existência humana antes do processo de instauração da propriedade privada: "Dotados de faculdades similares, dividindo tudo em uma única comunidade da natureza, nāo se pode conceber que exista entre nós uma 'hierarquia' que nos autorizaria a nos destruir uns aos outros, como se tivéssemos sido feitos para servir de instrumento às necessidades uns dos outros, da mesma maneira que as ordens inferiores da criação são destinadas a servir de instrumento às nossas." (LOCKE, 2001, II, § 6, p. 84, grifos meus)

${ }^{22}$ Nesta perspectiva, convém salientar que "quando se interpreta a propriedade para proteçāo da qual os seres ingressam na sociedade civil como se tratando de vida, liberdade e posses, todos os indivíduos (exceto os escravos) estāo qualificados para a cidadania; quando se interpreta como sendo bens ou fortuna, então apenas seus possuidores estão qualificados." (MACPHERSON, 1979, p. 259)
} 
tica instituída pelo contrato, possibilitando a fundação do regime representativo ${ }^{23}$.

Investido nas terras e nas atividades agrícolas, o dinheiro (capital), no sistema mercantil, tende a entrar em circulação ${ }^{24}$, multiplicando-se ilimitadamente, à medida que sobrepuja a imobilização que caracteriza o estágio que antecede a reprodução operada pelo juro e usura, para cujas fronteiras converge a noção quantificada e abstrata do valor, que possibilita o desenvolvimento econômico, a evolução comercial, a produção da riqueza material e moral dos indivíduos, tendo em vista a equivalência que se impōe, no sistema filosófico-político de Locke, entre o bem moral e o bem econômico.

O argumento principal de Locke (a favor do uso de dinheiro, justificando a acumulação grosseiramente iníqua de riqueza) era que, juntos, eles eliminam o desperdício, o que obviamente deve ser do interesse de cada membro singular da sociedade. Entretanto, na época em que o sistema de acumulação advogado por Locke alcança sua completa articulação, o desperdício deixou de ser um lamentável aspecto marginal desse sistema, e sim uma parte integrante e deliberadamente cultivada dele. Na verdade, o desperdício no sistema não está de maneira alguma restrito aos produtos perecíveis da natureza. Ao contrário, corre solto em todas as áreas de produção e consumo, destruindo completamente todas as justificativas (e racionalizaçōes) que Locke pôde agrupar em suas deduçōes a favor do sistema. $\mathrm{O}$ que garantiria o uso econômico apropriado dos recursos disponíveis - a riqueza acumulável que se autoexpande com sucesso e que seria ativada pela "durabilidade" do dinheiro - acaba por ser o maior inimigo da própria durabilidade e o agente da perdularidade absoluta. (MÉSZÁROS, 2011, p. 690, grifos do autor)
Consistindo em um instrumento capaz de possibilitar o monopólio do produto e da sua produção, o dinheiro alcança status de mercadoria principal, convergindo para interpor entre os proprietários dos meios de produção e os trabalhadores o "não-produtor", a saber, o comerciante, que se sobrepõe a ambos no sistema econômico-social que, tendente à progressiva racionalização, se the atribui um poder material que, baseado na circulação de bens e dinheiro que a sua própria lógica implica, inevitavelmente justifica a sua tradução em primazia político-jurídica, conforme demonstra a instituição do governo civil e do Estado sob a perspectiva de Locke.

Se a valorização econômica atribuída a uma determinada coisa se impōe ao ato de sua apropriação, consistindo em um resultado que justifica a propriedade individual, tornando-se o seu fundamento lógico, a sua condição de direito natural pressupōe um caráter ético-político que guarda correspondência com uma formação econômico-social baseada no poder conferido pelo artifício que encerra o equivalente e a medida universal do valor, a saber, o dinheiro, convergindo para um processo que tende a tornar preeminente o bem inaparente, gerado pela potencialização da moeda stricto sensu, em face do patrimônio oriundo da acumulação de bens imóveis (posses) por seu intermédio, engendrando a forma abstrata de mercadoria que através da venda e da compra se sobrepõe à diversidade das coisas concretas que integram as relaçōes de troca.

Nesse sentido, não é de modo algum acidental que Locke tenha se preocupado tanto em efetuar uma rápida transição do uso real para o pseudoconsumo que emana do "uso de dinheiro por consentimento mútuo". Na visão de Locke, o uso

\footnotetext{
${ }^{23}$ Tendo em vista que, correlacionada à teoria do consentimento e à teoria da propriedade, a teoria da confiança emerge como fundamento da delegação de poder no pensamento político de Locke, que converge para uma síntese que implica "uma explicaçāo do que torna os governos legítimos, em primeiro lugar (a teoria do consentimento), e de como, em segundo lugar, súditos e governantes devem interpretar suas relaçōes recíprocas (a teoria da confiança); depois, uma explicação de como os seres humanos podem ter direitos a possuir bens econômicos e a extensão e os limites desse direito (a teoria da propriedade); em seguida, uma explicação das similaridades e diferenças entre diversos tipos de autoridade humana e, acima de tudo, das diferenças entre a autoridade numa família e num Estado." (DUNN, 2003, pp. 45-46, grifos meus)

24 "A única acumulação que é pré-requisito do advento do capital é a da riqueza monetária que, considerada isoladamente, é inteiramente improdutiva, emergindo somente da circulação e pertencendo apenas à circulaçāo." (MARX, 1985, p. 109, grifos do autor)
} 
real é estreito e está perdulariamente circunscrito aos constrangimentos da natureza, fatos que se evidenciam tanto na perecibilidade dos objetos a serem consumidos como nas limitações dos próprios apetites humanos. Segundo ele, o uso de dinheiro foi consentimento mútuo e o fundamento justificador do "amontoar" e "ameaIhar" riqueza, de modo que "um homem pode possuir", por direito e sem injúria, "mais do que ele próprio pode usar" recebendo "ouro e prata", que ele pode guardar longamente em sua posse sem que se degenerem pelo excedente. De fato, pondo o carro na frente dos bois, Locke pode até mesmo representar falsamente as práticas artificiais e iníquas de acumular riquezas sociais e excluir outros de seus benefícios não como se fossem apenas plenamente conforme, mas diretamente originárias da própria natureza. Assim, ele argumenta: "Descubra-se algo que tenha o valor e o uso do dinheiro entre os vizinhos, e ver-se-á o mesmo homem começar imediatamente a amplificar o que possui". (MÉSZÁROS, 2011, pp. 689-690, grifos do autor)

A "autorização" para a ilimitada acumulação de riquezas que o direito à propriedade e a invenção do dinheiro encerram, caracterizando a formação econômico-social mercantilista do sistema filosófico-político de Locke ${ }^{25}$, converge para a multiplicação e a diferenciação dos carecimentos que, em face das distintas individualidades "econômicas" constitutivas da organização político-social, tende à "abstração" e à complexidade das relações econômicas em um sistema de contradições que assinala que se à minoria (a saber, os proprietários) cabe a possibilidade de desenvolver quantitativa e qualitativamente os carecimentos, a maioria permanece sob a égide de carecimentos que se restringem à sua autopreservação, segundo a conotação fundamental, originária, aplicada a este termo e que implica a sobrevida, mantendo raízes na existência natural e mais imediata dos homens.

Nesta perspectiva, o que se impōe é o valor intrínseco à terra atribuído pelo processo de monetarização da economia, que converge para tornar tal "propriedade" independente do fenômeno que se the confere a condição de direito baseado no exercício de posse ${ }^{26}$, constituindo-se o dinheiro a possibilidade da construção do monopólio de terras que, demandando um sistema produtivo capaz de se lhe corresponder, instaura as relações que, correspondendo à necessidade de sobrevida dos não proprietários, implicam a divisão do trabalho e a alienação, relegando-os, dessa forma, a reprodução de suas condiçōes de existência como membros de uma sociedade que destina à "minoria" representada pelos cidadãos as riquezas (posse real, usufruto $e$ multiplicação) ${ }^{27}$.

Atribuindo ao trabalho a condição de mercadoria, o sistema filosófico-político de Locke, caracterizando-o como propriedade do indivíduo, possibilita a sua inclusão nas relaçōes de troca entre proprietários de bens (fortunas) e não proprietá-

\footnotetext{
25 "O alvo da política mercantil e da empreitada econômica individual era, para Locke, o emprego da terra e do dinheiro como capital: o dinheiro deveria ser despendido em estoques comerciais, materiais e salários; a terra, usada para produzir artigos de comércio." (MACPHERSON, 1979, pp. 216-217)

${ }^{26}$ Alcança relevância, nesta perspectiva, a distinçāo entre propriedade natural e propriedade civil que Strauss identifica na teoria de Locke, que tende a conferir a esta última, a saber, à propriedade convencional, uma condição de primazia em relação àquela cuja aquisição e posse encerra meios e fins baseados nos princípios do direito natural e da sua justiça, guardando correspondência com a lei natural, que se sobrepōe às leis positivas ou civis, convergindo para delimitá-las: "A propriedade é uma instituição da lei natural; a lei natural define o modo e as limitaçōes da apropriação justa. Os homens possuem propriedade antes de haver sociedade civil; entram na sociedade civil com vista a preservar ou proteger a propriedade que adquiriram no estado de natureza. Mas, assim que se forma a sociedade civil, se é que não antes, a lei natural no que toca à propriedade deixa de ser válida; aquilo a que podemos chamar propriedade 'convencional' ou 'civil' - a propriedade que é possuída no seio da sociedade civil - baseia-se apenas na lei positiva. Porém, embora a sociedade civil seja a criadora da propriedade civil, nāo é sua senhora: a sociedade civil tem de respeitar a propriedade civil; a sociedade civil; por assim dizer, nāo tem outra funçāo senão servir a sua própria criaçāo. Locke reclama para a propriedade civil uma santidade muito maior do que para a propriedade natural; isto é, a propriedade que é adquirida e possuída exclusivamente com fundamento na lei natural, na 'lei suprema'." (STRAUSS, 2009, p. 201) ${ }^{27}$ Nesta perspectiva, cabe recorrer à análise de Marx: “A riqueza existente sob a forma de dinheiro só poderá ser trocada pelas condiçōes objetivas de trabalho, porque e se estas tiverem sido separadas do próprio trabalho. Já vimos que o dinheiro pode, em parte, ser acumulado pela simples troca de equivalentes; entretanto, esta é uma fonte tão insignificante que não merece mençāo, historicamente - uma vez que se presuma, isto é, que se considere que este dinheiro tenha sido ganho pela troca do trabalho próprio. É, preferencialmente, o dinheiro acumulado pela usura - especialmente a usura relacionada à propriedade da terra - e a riqueza móvel (monetária) acumulada através de lucros mercantis que se transformam em capital no estrito senso, em capital industrial." (MARX, 1985, pp. 100-101, grifos meus)
} 
rios em função da necessidade de assegurar a sua autoconservação no âmbito de uma organização que traz a propriedade privada e a divisão do trabalho como eixos que articulam a sua formação econômico-social, fundamentando-a como tal.

A possibilidade de ilimitada acumulação de riquezas (bens, fortunas) que o monopólio da propriedade engendra através da introdução do dinheiro nas relaçōes de troca converge para as fronteiras que encerram a divisão social do trabalho, o trabalho assalariado e a divisão da sociedade em classes, implicando uma formação econômico-social que traz contradiçōes insuperáveis, à medida que tende a multiplicar as desigualdades que se impōem às relaçōes entre "proprietários" e trabalhadores (produtores), tendo em vista que desde o sistema produtivo até a esfera política a ordem ético-jurídica e político-social carrega uma lógica que detém todas as condiçōes necessárias e suficientes para a reprodução de sua existência como tal28.

Nesta perspectiva, ao imperativo ético-lógico que se impõe à acumulação ilimitada de bens que a invenção do dinheiro acarreta no estado de natureza, o que cabe ao estado civil é instituir, pelo consentimento da maioria, uma legislação capaz de coibir tais práticas, evitando, dessa forma, a multiplicação das desigualdades ${ }^{29}$ : o problema é que, atribuindo a condição de cidadania apenas aos proprietários, como os representantes eleitos se thes podem contrapor, definindo leis que se Ihes sejam contraditórias? E se é o princípio da maioria que determina o destino da sociedade, o bem público, que se lhe está imbricado, não guarda correspondência senão com a vontade de todos (maioria), servindo para reproduzir as condiçōes objetivas, materiais, da organização, do Estado como totalidade ético-jurídica, econômico-social e lógico-política ${ }^{30}$.

\section{Aspectos Conclusivos}

Se o indivíduo detém um poder absoluto (soberania) sobre si no estado de natureza, a transição para o estado cívico não se lhe priva desta condição, conforme a perspectiva de Locke, mas se Ihe confere base legal para o seu exercício através da instituição do Estado jurídico, razão pela qual ao legislativo cabe apenas uma supremacia de caráter relativo, convergindo para uma função que corresponde às necessidades dos indivíduos que consentiram na sua criação e que, elegendo os seus representantes, teoricamente se lhes imbuem do conteúdo que à legislação compete

\footnotetext{
${ }^{28}$ Nesta perspectiva, alcança relevância que, guardando correspondência com a divisāo social do trabalho e o seu caráter funcional, a divisāo hierárquica do trabalho converge para o processo de reprodução do capital, segundo a leitura de Mészáros, que esclarece que "esta imposição da divisāo social hierárquica do trabalho como força cimentadora mais problemática - em última análise, realmente explosiva - da sociedade é uma necessidade inevitável. Ela vem da condição insuperável, sob o domínio do capital, de que a sociedade deva se estruturar de maneira antagônica e específica, já que as funçōes de produçāo e de controle do processo de trabalho devem estar radicalmente separadas uma da outra e atribuídas a diferentes classes de indivíduos. Colocando de forma simples, o sistema do capital - cuja raison d'être é a extração máxima do trabalho excedente dos produtores de qualquer forma compatível com seus limites estruturais - possivelmente seria incapaz de preencher suas funçōes sociometabólicas de qualquer outra maneira. Por outro lado, nem mesmo a ordem feudal institui esse tipo de separação radical entre o controle e a produção material. Apesar da completa sujeição política do servo, que o priva da liberdade pessoal de escolher a terra em que trabalha, no mínimo ele continua dono de seus instrumentos de trabalho e mantém um controle não formal, mas substantivo, sobre boa parte do processo de produçāo em si." (MÉSZÁROS, 2011, p. 99, grifos do autor)

${ }^{29}$ Convém observar que o processo de transformaçāo da posse em propriedade através do trabalho, que se lhe atribui a condiçāo de um direito natural, converge para a delimitação imposta pela lei natural no sentido de impedir que o exercício da referida apropriação gere o desperdício ou antes subtraia dos demais indivíduos os meios e as condiçōes necessárias que, representadas pelo investimento na terra que a relação homem-natureza implica, possibilitam a sua subsistência, a sua autoconservaçāo, constituindo-se um princípio de justiça natural que, entretanto, perde o valor no estado cívico, que legitima a acumulação e a desigualdade, a despeito de que, conforme Locke afirma, "é certo que esta lei [natural] existe, absolutamente inteligível e clara para uma criatura racional dedicada a seu estudo, como o são as leis positivas da comunidade civil; ou melhor, possivelmente mais claras, pois a razão é mais fácil de ser compreendida que os sonhos e as maquinaçōes intrincadas dos homens, buscando traduzir em palavras interesses contrários e ocultos; pois assim realmente se constitui grande parte das leis civis dos países, que só sāo justas na medida em que se baseiam na lei da natureza, pela qual devem ser regulamentadas e interpretadas." (LOCKE, 2001, II, § 12, p. 88)

30 Tendo em vista que "na maior parte dos Estados históricos, os direitos concedidos aos cidadāos sāo regulados de acordo com as posses dos referidos cidadāos, pelo que se evidencia ser o Estado um organismo para a proteçāo dos que possuem contra os que nāo possuem. Foi o que vimos em Atenas e em Roma, onde a classificação da população era estabelecida pelo montante dos bens. O mesmo acontece no Estado feudal da Idade Média, onde o poder político era distribuído conforme a importância da propriedade territorial. Eé o que podemos ver no censo eleitoral dos modernos Estados representativos." (ENGELS, 1984, p. 194, grifos meus)
} 
contemplar em um processo que implica uma auto-obrigação jurídica que se sobrepõe ao horizonte condicional do estágio que antecede a instauração da coercibilidade que advém da sociedade política.

Guardando condição de imanência em relação ao estado de natureza, as leis naturais se impōem à existência dos homens como uma espécie de virtude natural, à medida que escapa à égide de um direito que automaticamente emerge e dessa forma converge para a sua realização, tendo em vista que, embora caracterizandose pela universalidade, a sua aplicação não consiste senão no resultado de uma síntese de condições objetivas que se correlacionam com as avaliaçōes subjetivas em um processo que pressupõe a impossibilidade de uma identidade perfeita entre os homens e de uma adesão unânime das consciências, constituindose o Direito, em última instância, em face das diferenças físicas, intelectuais e morais passíveis de tradução em "desigualdades", na possibilidade de concretização da proporcionalidade.

Baseado no direito de propriedade, o sistema filosófico-político de Locke converge para a centralização e concentração de riquezas, à medida que o contratualismo encerra a capacidade de produzir as condiçōes objetivas para a instauração de um progresso que não pode prescindir da divisão social do trabalho, do trabalho assalariado e da divisão em classes da sociedade, tendo em vista a necessidade de investir os esforços dos indivíduos no sentido de construir o conjunto de riquezas que a satisfação dos carecimentos singulares demanda em um processo que, atendendo aos interesses privados, contribui para o bem-estar geral que hipoteticamente o Estado encarna.

Se a transição do estado de natureza para o estado cívico envolve o processo de instituição do conjunto sistemático das normas asseguradas pela autoridade pública, em consonância com a perspectiva que implica a existência de direitos naturais inatos que guardam anterioridade lógica e cronológica concernente à organização estatal, o que se impōe ao poder legislativo é uma supremacia de caráter relativo, cujo exercício, circunscrevendo a criação do Direito Positivo às fronteiras em questão, se sobrepõe à concepção que reduz o Direito Positivo à condição de Direito Estatal, convergindo para uma noção de soberania que se detém na esfera da sociedade civil, embora restrita aos cidadãos, e na sua relação com o legislativo, escapando ao monopólio do governo civil e resultando de um conjunto que, em última instância, se mantém sob controle dos indivíduos enquanto povo que, dessa forma, conserva a capacidade de autodeterminação e de auto-obrigação jurídicas.

Instituindo uma ordem econômico-jurídica que traz em seu arcabouço uma hierarquia que sobrepōe os cidadãos aos membros, os ricos aos pobres, os "proprietários" aos "trabalhadores", o sistema filosófico-político de Locke encerra uma lógica que supõe diferentes "níveis" de racionalidade no processo de distribuição dos indivíduos na organização das forças produtivas, cujo funcionamento não apenas admite mas demanda a alienação dos homens que, em função da sua autoconservação, tornam-se protagonistas de um resultado econômico-social destinado à construção de riquezas e à satisfação de interesses e vontades particulares daqueles que, perfazendo uma minoria, detêm autorização do Estado jurídico para indiscriminadamente monopolizá-las.

Às relaçōes políticas instauradas através da instituição da sociedade política e do Estado jurídico, o que se impōe é uma formação econômico-social que guarda correspondência com as açōes atomísticas dos indivíduos singulares que, trazendo como fundamento um liame constante e necessário entre si, convergem para a emergência de uma finalidade interior que se lhes determina, perfazendo um conjunto organizado que expressa a verdade da vida econômica por intermédio de um corpo daquilo que ora se de- 
signa como leis ${ }^{31}$, sob cuja égide a economia monetária advém e impera, resultando, contudo, em um desajuste que tende a introduzir no sistema contradiçōes insuperáveis e antagonismos inelutáveis que culminam na transformação do indivíduo em um meio por intermédio do qual o outro leva a efeito as suas vontades e interesses, tendo em vista o endosso jurídico que as desigualdades alcançam no estado cívico.

As diferenças físicas, intelectuais e morais, ou um hipotético resultado obtido através de um processo que haja implicado desde a apropriação inicial de terras até a acumulação de riquezas engendrada pela invenção do dinheiro, ou a correlação de ambos em uma condição de existência pré-cívica ou pré-política, não pode se constituir como fundamento de uma desigualdade de fato que a instauração do contrato e da sociedade política que se lhe advém, fundando o Estado jurídico, transforme em desigualdade de direito, se lhe conferindo uma base jurídica que traz a distinção não apenas formal mas substancial entre membros da organização político-social e cidadãos, pobres e ricos, "trabalhadores" e "proprietários", determinando definitivamente o destino dos indivíduos em face de uma hierarquização insuperável que, escapando ao paradigma do direito natural, torna a liberdade proporcional ao grau de igualdade usufruída na concreticidade da vida econômico-social e histórico-cultural do homem em sua individualidade singular.

Partindo da suposição tradicional de que a terra e seus frutos haviam sido inicialmente dados ao gênero humano para o uso em comum, virou o feitiço contra os feiticeiros - contra os que deduziam dessa suposição teorias que limitavam a apropriação capitalista. Apagou a incapacidade jurídica pela qual a apropriação capitalista havia sido, até então, entravada. Se não tivesse feito mais do que isso, sua contribuição teria de ser aceita como considerável. Mas ele fez ainda mais. Justificou, como natural, uma diferenciação de direitos e de raciocínios, e assim fazendo, forneceu uma base moral positiva para a sociedade capitalista. (MACPHERSON, 1979, p. 233)

A conexão e a interdependência ininterrupta envolvendo interesses materiais e poder político, formação econômico-social e sistema político-jurídi$\mathrm{co}$, eis o que se impõe ao contratualismo de Locke, que converge para legitimar a força e a hegemonia do capita ${ }^{\beta 2}$ na instituição da sociedade política e do Estado, cuja existência então implica a necessidade de assegurar a "racionalidade" inscrita nas relaçōes "atomísticas" desenvolvidas pelos indivíduos como agentes econômicos em um processo que demanda condiçōes objetivas capazes de possibilitar a transformação da natureza em produto, consubstanciando um patrimônio passível de usufruto pelos homens em virtude da satisfação de seus progressivos carecimentos em uma conjuntura que simultaneamente gera a riqueza material da coletividade, a despeito do monopólio dos meios de produção exercido pela minoria (proprietários) em detrimento dos demais e da canalização dos bens e recursos em todos os sentidos em benefício dos tais, tendo em vista o atrelamento inelutável entre a noção que encerra o bem-estar geral e o desenvolvimento econômico-social.

\section{Referências bibliográficas}

CHÂTELET, François, DUHAMEL, Olivier, PISIER-KOUCHNER, Evelyne. História das Ideias Políticas. Trad. de CarIos Nelson Coutinho. 2. ed. Rio de Janeiro: Zahar, 1990.

\footnotetext{
${ }^{31}$ Convém salientar que, baseada no direito de propriedade que o trabalho instaura, a existência pré-cívica encerra relaçōes e atividades que implicam desde a produção até o comércio, convergindo para um processo que demanda a invenção do dinheiro e a emergência do trabalho assalariado em um sistema econômico-social que, segundo a teoria de Locke, guarda correspondência com a ordem natural, caracterizando-se, por essa razão, por um funcionamento cuja lógica não permanece passível de intervenção do Estado.

32 "Como vimos, o conceito de capital - a origem - implica dinheiro como ponto de partida e, portanto, implica a existência de riqueza em forma de dinheiro. Está igualmente implícita sua procedência da circulação; o capital surge como o produto da circulação. A formação do capital, portanto, não se origina da propriedade da terra (embora possa derivar dos arrendatários agrícolas na medida em que sejam, também, comerciantes de produtos agropecuários), nem das corporaçōes (embora estas constituam, também, uma possibilidade) mas da riqueza mercantil e usurária. Porém, os comerciantes e usurários somente encontram condiçōes que permitem a compra de trabalho livre quando este foi separado das condiçōes objetivas de sua existência, em consequência de um processo histórico. Aí, torna-se possível, também, comprar as próprias condiçōes." (MARX, 1985, p. 101, grifos do autor)
} 
DELLA VOLPE, Galvano. Rousseau e Marx: a liberdade igualitária. 4. ed. Lisboa: Edições 70, s.d.

DUNN, John. Locke. Trad. de Luiz Paulo Rouanet. São PauIo: Loyola, 2003.

ENGELS, Friedrich. A origem da família, da propriedade privada e do estado. Trad. de Leandro Konder. 9. ed. Rio de Janeiro: Civilização Brasileira, 1984.

FILMER, Robert. Patriarcha and other writings. Cambridge: Cambridge University Press, 1991.

LOCKE, John. Ensaio sobre o Entendimento Humano. Trad. de Eduardo Abranches de Soveral. Lisboa: Fundação Calouste Gulbenkian, 1999.

Segundo tratado sobre o governo civil: ensaio sobre a origem, os limites e os fins verdadeiros do governo civil. Trad. de Magda Lopes e Marisa Lobo da Costa. 3 ed. Petrópolis/RJ: Vozes, 2001.

MACPHERSON, Crawford Brough. A teoria política do individualismo possessivo: de Hobbes a Locke. Trad. de Nelson Dantas. Rio de Janeiro: Paz e Terra, 1979.
MANENT, Pierre. História intelectual do liberalismo. Trad. de Vera Ribeiro. Rio de Janeiro: Imago, 1990.

MARX, Karl. Formações econômicas pré-capitalistas. Trad. de João Maia. 4. ed. São Paulo: Paz e Terra, 1985.

MÉSZÁROS, István. Para além do capital: rumo a uma teoria da transição. Trad. de Paulo Cezar Castanheira e Sérgio Lessa. 1. ed. rev. São Paulo: Boitempo, 2011.

MICHAUD, Ives. Locke. Trad. de Lucy Magalhães. Rio de Janeiro: Zahar, 1991.

MORA, José Ferrater. Dicionário de Filosofia. Tomo III (KP). Trad. de Maria Stela Gonçalves et al. 2. ed. São Paulo: Loyola, 2004.

STRAUSS, Leo. Direito natural e história. Trad. de Miguel Morgado. Lisboa: Ediçōes 70, 2009.

\section{Luiz Carlos Mariano da Rosa}

Graduado em Filosofia pelo Centro Universitário Claretiano (CEUCLAR/SP) e Pós-Graduado em Filosofia pela Universidade Gama Filho (UGF/RJ); Professor-Pesquisador e Filósofo-Educador no Espaço Politikón Zôon Educação, Arte e Cultura. Autor de O Todo Essencial, Universitária Editora, Lisboa, Portugal, Quase Sagrado, Politikón Zôon Publicaçōes, São Paulo, Brasil, Mito e Filosofia: Do Homo Poeticus, Politikón Zôon Publicaçōes, São Paulo, Brasil, e, entre outros, 0 Direito de Ser Homem, Politikón Zôon Publicaçōes, São Paulo, Brasil. 